\title{
Radiological Pharmacology Drugs: Therapeutic Potential of Melatonin
}

https://doi.org/10.37336/2707-0700-2020-4-5

\section{N.N. Kolotilov \\ SI «Institute of Nuclear Medicine and Diagnostic Radiology of NAMS of Ukraine», Kyiv, Ukraine}

In fundamental reference books, the description of the real spectrum of pharmacologic and therapeutic activity of this or that drug is presented very limitedly. Every year, for a long time, our knowledge of the true spectrum of activity in the process of painstaking scientific research work is expanded. However, these results practically do not penetrate from journal articles, dissertations' abstracts, abstracts in reference books on clinical pharmacology. It is enough to compare the increase of information in revised and supplemented editions [6].

The purpose of the article is to draw attention to Melatonin as a means of radiological pharmacology within the framework of drugs' reprofiling [13] and the "off-label" strategy (application for medical purposes does not correspond to the instructions for the basic medical use of the drug).

The pineal gland, located in the geometric center of the human brain, is an organ of the diffuse endocrine system. Melatonin (5-methoxy-N-acetyltryptamine, $\mathrm{C}_{13} \mathrm{H}_{16} \mathrm{~N}_{2} \mathrm{O}_{2}$, molar mass $-232.278 \mathrm{~g} / \mathrm{mol})$ is the main hormone of the pineal gland ( $80 \%$ of total systemic melatonin), an endogenous integrator, chronomod- ulator and regulator of the body's circadian rhythms. The maximum secretion of melatonin is observed at night, the minimum - during the day (Figure) [2].

The body also contains extrapineal (formed outside the pineal gland) Melatonin. In 1974, it was discovered that Melatonin is synthesized in the cells of the appendix of the intestine. Then it was found out that this hormone is also formed in other parts of the gastrointestinal tract, in many other organs - liver, kidneys, adrenal glands, gall bladder, ovaries, endometrium, placenta, thymus, as well as in leukocytes, platelets, lymphocytes and in the endothelium, retina, bone marrow and skin cells $[2,15,16]$. The biological effect of extrapineal Melatonin is realized directly where it is formed [7].

Melatonin is a versatile molecule, widely distributed in nature and found in unicellular organisms, plants, mushrooms and animals. For a long time, Melatonin was perceived exclusively as a substance that is effective in treating disturbances in biological rhythms and for sleep normalization. At the same time, a large number of resent studies demonstrate a wide range

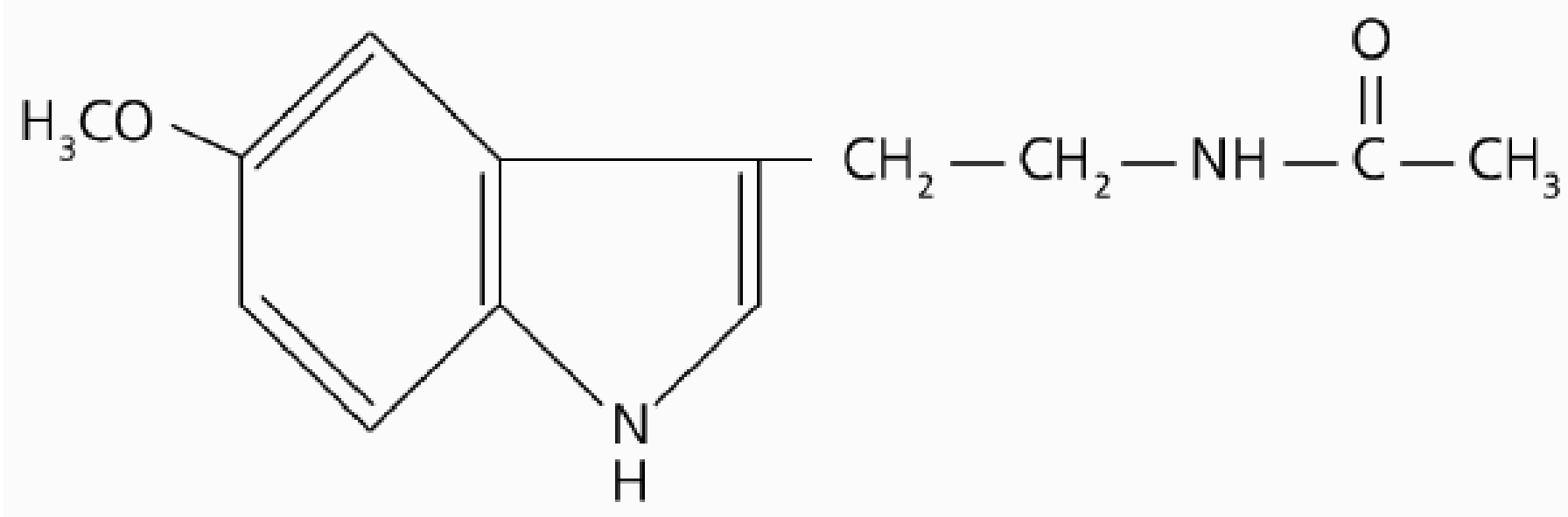

Structural formula of Melatonin [2]. 
of pharmacological and therapeutic activity of melatonin $[15,16]$.

Melatonin has, to varying degrees, a dose-dependent antistressor, sedative, hypnogenic, neuroprotective, geroprotective (a general consistent pattern for all geroprotectors - earlier initiation of drug use provides a greater effect), antidepressant, antioxidant, antitumor, antiapoptotic (in normal cells), proapoptotic (in cancer cells), oncostatic, antimetastatic, immunomodulatory, radioprotective, radiosensitizing, anti-infectious, analgesic, hepatoprotective, antihypertensive, anti-inflammatory, moderate contraceptive (for women) action [1-5, 7-12, 14-20]. Melatonin regulates neuroendocrine functions, respiratory rate, reproductive function, osteogenic differentiation of mesenchymal stem cells, formation and protection of bones; modulates the activity of bone-forming osteoblasts and bone-resorbing osteoclasts; reduces pain sensitivity; affects the intracellular calcium content [7].

The antioxidant properties of Melatonin are closely related to its antitumor effect. Studies have demonstrated that melatonin has a selfsufficient oncostatic effect in cancer of the breast, ovaries, endometrium, pancreas, prostate, lungs; melanoma, hepatocellular carcinoma, colorectal cancer, glioblastoma, and leiomyosarcoma [15].

In clinical work on patients with myeloma and lymphocytopenia, Melatonin in combination with standard antitumor therapy for these diseases suppressed the growth of tumor cells and contributed to the sensation of subjective improvement and to the increase in the patient's quality of life [7].

Melatonin inactivates intracellular free radicals and limits lipid peroxidation processes, provides universal protection of any living cells from damage. According to modern concepts, Melatonin at the cellular level can determine the origin of various types of pathology, regardless of whether it affects the brain tissue, heart muscle, liver or any other organ. This biological property of Melatonin, obviously, is primarily associated with its universal ability to weaken the side effects of various pharmacotherapy. Therefore, Melatonin is indicated for various types of drug and non-drug intoxication. In particular, its reliable antitoxic effect has been demonstrated in case of overdose of various medicines, poisoning with industrial poisons, heavy metal salts [4].

The universal therapeutic potential of Melatonin is based on the unique ability to interfere in almost any physiological process: never determining any of them, melatonin, in the event of a deviation of a process from the norm, invariably ensures its universal corrective regulation of an adaptive nature [3-5].

Radiobiology. Melatonin was discovered in 1958 , and its radioprotective effect was revealed in $1959[16,19]$.

In studies [9], the optimal regimes (doses and terms) of Melatonin application as a means of protecting the chromosomal apparatus from the clastogenic action of cytostatic drugs and ionizing radiation have been developed. A system of criteria for assessing the preventive effect of Melatonin under conditions of exposure to xenobiotics and ionizing radiation effects on the body is proposed. This system includes the determination of cytogenetic parameters (various types of chromosomal aberrations in bone marrow cells), proliferative and migratory activity of peripheral blood leukocytes, as well as the proliferation of lymphoid tissue.

Irradiation of rats at a dose of $4 \mathrm{~Gy}$ is accompanied by an increase in the intensity of lipid peroxidation processes and a decrease in the activity of the antioxidant system, which indicates the development of post-radiation oxidative stress. The use of Melatonin 30 minutes before irradiation helps to normalize the processes of free radical oxidation. In non-irradiated rats, Melatonin causes an increase in both prooxidant and antioxidant activity [9].

In an experiment on mice, it was demonstrated that Melatonin protects the male reproductive system from radiation damage.

These results can be additionally used for the application of Melatonin in radiation therapy of malignant pelvic tumors in men [14].

Melatonin $(100 \mathrm{mg} / \mathrm{kg}$ of melatonin $30 \mathrm{~min}-$ utes before irradiation and $5 \mathrm{mg} / \mathrm{kg}$ once a day (by day) for 30 days) improves the biochemical, electrophysiological and morphological characteristics of irradiated tissues of the gastrocnemius muscle of rats (a single dose of gamma radiation $30 \mathrm{~Gy}$ ) [18 ].

The influence of Melatonin on radiationinduced cataract. The experiment established 
the anticataractogenic activity of Melatonin: 5 $\mathrm{mg} / \mathrm{kg} /$ day daily by intraperitoneal injections for 10 days against radiation-induced cataract in the lens after total irradiation of the skull of rats with a single dose of 5 Gy. Total skull irradiation with $5 \mathrm{~Gy}$ in a single dose increased cataract formation, and the addition of Melatonin protected the lenses from radiation-induced cataract formation.

Adjuvant therapy supplemented with Melatonin may reduce the number of patients suffering from toxic therapeutic regimens such as chemotherapy and/or radiation therapy, and may provide symptom relief from radiation-induced organ damage [12].

In clinical practice, Mmelatonin is in much less demand than one would expect based on the above. But there is a clear gap between the large number of experimental studies that substantiate the effectiveness of Melatonin in models of pathological conditions, and the relatively small number of placebo-controlled large-scale clinical observations.

Melatonin ( endogenously produced molecule) in a very wide range of doses is free of cytotoxicity (in normal cells) and does not negatively affect the frequency of mutations, does not provoke serious side effects, which makes it possible to use it in an extremely wide range of doses. Indeed, in some experimental studies one can sometimes find difficult to explain indications of the ability of Melatonin to provide protection of animals with almost equal success, for example, from traumatic brain injury, when administered, on the one hand, in relatively moderate $(1-1.5 \mathrm{mg} / \mathrm{kg})$, and on the other - in simply gigantic doses $(200-300 \mathrm{mg} / \mathrm{kg})$.

Unlike most pharmacological agents, Melatonin is characterized by a U-shaped response curve (and not a typical linear dose-effect relationship), when with dose increasing the effect sometimes does not increase, but, on the contrary, decreases and can even have a negative value. Thus, in one of the studies on rats, chronic administration of melatonin at lower doses ( 5 and $15 \mathrm{mg} / \mathrm{kg}$ ) reduced the oxidative stress, while under the influence of a high dose (150 $\mathrm{mg} / \mathrm{kg}$ ), a reverse shift was established with an increase in stress manifestations [3-5].

For optimal use of Melatonin, which have a clear daily and seasonal rhythm of natural secre- tion, it is important to choose an adequate time of its' intake. In most clinical studies, Melatonin intake is fairly timed to late evening hours, but the need to vary the dose depending on the season is rarely taken into account [8].

It is necessary to include additional laboratory control methods in the therapeutic tactics in the treatment with Melatonin. The severity of the pharmacological Melatonin effect in individual subjects should already a priori be noticeably influenced by the initial hormonal background on which it is used. It is important to take into account the curve of the patient's daily production of Melatonin by his own pineal gland, and not only the absolute values of the hormone content in biological fluids (blood, urine, saliva).

Knowledge engineering. More complete information on melatonin is presented in reviews [15, 16], covering 386 and 193 sources, respectively.

Conflict of interest information. The author declares no conflicts of interest related to the publication of this article.

\section{Literature}

1. Абсатарова Ю. С. Роль мелатонина в патогенезе синдрома поликистозных яичников: дис. ... канд. мед. наук: 14.01.02 / Юлия Сергеевна Абсатарова; [Нац. мед. исследовательский центр эндокринологии], 2018. - 100 с.

2. Анисимов В. Н. Свет, старение и рак / В. Н. Анисимов // Природа. - 2018. - № 6. C. 19-22.

3. Арушанян Э. Б. Участие мелатонина в защите организма от инфекционной патологии / Э. Б. Арушанян // Обзоры по клин. фармакологии и лекарственной терапии. -2014. - № 1. - С. 3-9.

4. Арушанян Э. Б. Противовоспалительные возможности мелатонина/ Э.Б. Арушанян С.С. Наумов // Клиническая медицина. - 2013. - № 7 . - С. 18-22.

5. Арушанян Э. Б. Мелатонин как универсальный модулятор любых патологических процессов / Э. Б. Арушанян, Е. В. Щетинин // Патологическая физиология и экспериментальная терапия. - 2016. - № 1. - С.79-88.

6. Компендиум 2018 - лекарственные препараты / под. ред. В. Н. Коваленко, А. П. Викторова. - К.: Морион, 2018. - 1664 с. 
7. Курганова Ю. М. Роль мелатонина в терапии хронической боли в спине: дис. ... канд. мед. наук: спец. 14.01.11 / Юлия Михайловна Курганова; [1-й Московский мед. ун-тет им. И.М. Сеченова], 2017. - 106 с.

8. Мамчур В. И. Мелатонин как вспомогательная терапия при COVID-19 / В. И. Мамчур, Д. С. Носивец, Е. В. Хомяк // Сімейна медицина. - 2020. - № 3. - С. 13-19.

9. Пикалова Л. В. Генопротективные эффекты мелатонина при химических и радиационных воздействиях: экспериментальное исследование: дис. ... канд. биол. наук: спец. 14.03.04, 03.01.01 /Лидия Васильевна Пикалова; [Ин-т токсикологии]. - СПб., 2012. - 111 c.

10. Севастьянова Н. Н. Молекулярно-клеточные механизмы радиационного старения: автореф. дис. ... д-ра биол. наук: спец. 14.01.30 / Наталья Николаевна Севастьянова; [Санкт-Петербургский институт биорегуляции и геронтологии РАМН]. - СПб, 2013.

11. Farhood B. Melatonin as an adjuvant in radiotherapy for radioprotection and radiosensitization / B. Farhood, N. H. Goradel, K. Mortezaee // Clinical and Translational Oncology. - 2019. - Vol. 21. - P. 268-279. https://doi. org/10.1007/s12094-018-1934-0.

12. Karslioğlu I. Effects of Melatonin on Radiation-Induced Cataract / I. Karslioğlu, M. Ertekin, S. Taysi // Journal of Radiation Research. - 2005. - Vol. 46(2). - P. 277-282. https://doi.org/10.1269/jrr.46.277.

13. Kolotilov N. N. Repurposing of Drugs: Radiological Aspect / N. N. Kolotilov, A. Alekseyenko, I. V. Andrushchenko, S. Anton // Лучевая диагностика, лучевая терапия. - 2019. - № 3. - C. 62-65. https://doi.org/10.37336/27070700-2019-3-7.

14. Khan S. Radioprotective potential of melatonin against ${ }^{60} \mathrm{Co} \gamma$-ray-induced testicular injury in male C57BL/6 mice / S. Khan, J. S. Adhikari, M. A. Rizvi // J Biomed Sci. - 2015. - Vol. 22. - P. 61. https://doi.org/10.1186/ s12929-015-0156-9.

15. Reiter R. J. Melatonin a Full Service AntiCancer Agent: Inhibition of Initiation, Progression and Metastasis / R. J. Reiter, S. RosalesCorral, D. X. Tan // Int. J. Mol. Sci. - 2017. - Vol. 18. - P. 843. https://doi.org/10.3390/ ijms18040843.
16. Reiter R. J. Melatonin as a mitochondria-targeted antioxidant: one of evolution's best ideas / R. J. Reiter, S. Rosales-Corral, D. X. Tan // Cell Mol Life Sci. - 2017. - Vol. 74(21). - P. 3863-3881. https://doi.org/10.1007/ s00018-017-2609-7. Epub 2017 Sep 1. PMID: 28864909.

17. Semiglazova T. U. Perspectives of melatonin use in clinical oncology / T. U. Semiglazova, M. A. Osipov, A. V. Novik // Malignant Tumours. - 2016. - N 4. - P. 21-29. https:// doi.org/10.18027/2224-5057-2016-4-21-29.

18. Shabeeb D. Evaluation of the Radioprotective Effects of Melatonin Against Ionizing Radiation-Induced Muscle Tissue Injury / D. Shabeeb, M. Keshavarz, A. Shirazi // Curr Radiopharm. - 2019. - Vol.12(3). - P. 247-255. https://doi.org/10.2174/1874471012666190219 120329. PMID: 30806333.

19. Shirazi A. A Radiobiological Review on Melatonin: A Novel Radioprotector / A. Shirazi, G. Ghobadi, M. Ghazi-Khansari // Journal of Radiation Research. - 2007. - N 4. - P. 263272. https://doi.org/10.1269/jrr.06070.

20. Tresguerres I. F. Melatonin dietary supplement as an anti-aging therapy for age-related bone loss / I. F. Tresguerres, F. Tamimi, H. Eimar // Rejuvenation Res. - 2014. - Vol.17(4). - P. 341-346.

\section{RADIOLOGICAL PHARMACOLOGY DRUGS: THERAPEUTIC POTENTIAL OF MELATONIN}

\section{N.N. Kolotilov}

The purpose of the article is to draw attention to Melatonin as a means of radiological pharmacology within the framework of drugs' reprofiling [13] and the "off-label" strategy (application for medical purposes does not correspond to the instructions for the basic medical use of the drug).

Melatonin has, to varying degrees, a dose-dependent antistressor, sedative, hypnogenic, neuroprotective, geroprotective (a general consistent pattern for all geroprotectors - earlier initiation of drug use provides a greater effect), antidepressant, antioxidant, antitumor, antiapoptotic (in normal cells), proapoptotic (in cancer cells), oncostatic, antimetastatic, immunomodulatory, radioprotec- 
tive, radiosensitizing, anti-infectious, analgesic, hepatoprotective geroprotective, antihypertensive, anti-inflammatory, moderate contraceptive (for women) action. Melatonin regulates neuroendocrine functions, respiratory rate, reproductive function, osteogenic differentiation of mesenchymal stem cells, formation and protection of bones; modulates the activity of bone-forming osteoblasts and bone-resorbing osteoclasts; reduces pain sensitivity; affects the intracellular calcium content.

The antioxidant properties of Melatonin are closely related to its antitumor effect. Studies have demonstrated that melatonin has a self-sufficient oncostatic effect in cancer of the breast, ovaries, endometrium, pancreas, prostate, lungs; melanoma, hepatocellular carcinoma, colorectal cancer, glioblastoma, and leiomyosarcoma.

Key words: pineal gland, melatonin, radioprotector, radiological pharmacology.

\section{ЛІКАРСЬКІ ЗАСОБИ РАДІОЛОГІЧНОӤ ФАРМАКОЛОГІЇ: ТЕРАПЕВТИЧНИЙ ПОТЕНЦАЛ МЕЛАТОНІНУ}

\section{М.М. Колотілов}

Мета статті - в рамках перепрофілювання лікарських засобів і стратегіï «off-label» (застосування з медичною метою не відповідає інструкції по основному для медичного застосування препарату) звернути увагу на мелатонін, як на засіб радіологічної фармакології.

Мелатонін має в тій чи іншій мірі дозозалежу від його дози антістрессорну, седативну, гіпногенну, нейропротекторну, геропротекторну (загальна закономірність для всіх геропротекторов: ранній початок використання лікарського засобу забезпечує більший ефект), антідепресантну, антиоксидантну, протипухлинну, антиапоптозну (в нормальних клітинах), проапоптозну (в ракових клітинах), онкостатичну, антиметастатичну, імуномодулюючу, радіопротекторну, радіосенсібілізуючу, антиінфекційну, аналгетичну, гепатопротекторну, антигіпертензивну, протизапальну, помірну контрацептивну (на жінок) дію.

Мелатонін регулюе нейроендокринні функції, частоту дихальних рухів, репродуктивну функцію, остеогенне диференціювання мезенхімальних стовбурових клітин, формування та захист кісток; модулює ак- тивність кістково-утворюючих остеобластів і кістково-резорбуючих остеокластів; знижує больову чутливість; впливає на внутрішньоклітинний вміст кальцію.

Ключові слова: шишковидне тіло, мелатонін, радіопротектор, радіологічна фармакологія.

\section{ЛЕКАРСТВЕННЫЕ СРЕДСТВА РАДИОЛОГИЧЕСКОЙ ФАРМАКОЛОГИИ: \\ ТЕРАПЕВТИЧЕСКИЙ ПОТЕНЦИАЛ МЕЛАТОНИНА}

\section{Н.Н. Колотилов}

Цель статьи - в рамках перепрофилирования лекарственных средств и стратегии «оfflabel» (применение с медицинской целью не соответствует инструкции по основному медицинскому применению препарата) обратить внимание на мелатонин, как на средство радиологической фармакологии.

Мелатонин обладает в той или иной степени дозозависимым антистрессорным, седативным, гипногенным, нейропротекторным, геропротекторным (общая закономерность для всех геропротекторов: раннее начало использования лекарственного средства обеспечивает больший эффект), антидепрессантным, антиоксидантным, противоопухолевым, антиапоптозным (в нормальных клетках), проапоптозным (в раковых клетках), онкостатическим, антиметастатическим, иммуномодулирующим, радиопротекторным, радиосенсибилизирующим, антиинфекционным, анальгетическим, гепатопротекторным, антигипертензивным, противовоспалительным, умеренным контрацептивным (на женщин) действием. Мелатонин регулирует нейроэндокринные функции, частоту дыхательных движений, репродуктивную функцию; остеогенную дифференцировку мезенхимальных стволовых клеток, формирование и защиту костей; модулирует активность костно-образующих остеобластов и костно-резорбирующих остеокластов; снижает болевую чувствительность; влияет на внутриклеточное содержание кальция.

Ключевые слова: шишковидное тело, мелатонин, радиопротектор, радиологическая фармакология. 